\title{
COMPARISON OF THE COOMBS TEST WITH OTHER METHODS FOR BRUCELLA AGGLUTININS IN HUMAN SERUM ${ }^{1}$
}

\author{
By WENDELL H. HALL AND ROBERT E. MANION \\ (From the Veterans Administration Hospital, Minneapolis, Minn. and the Department of \\ Medicine, The Medical School, University of Minnesota)
}

(Submitted for publication September 12; accepted November 3, 1952)

During the past year we have compared several techniques for testing human sera for Brucella agglutinins. These have included a tube dilution method, the rapid slide method (Huddleson) and a rapid slide or screening test designed by Castaneda (1). In addition, a blocking test and a modification of the indirect Coombs test were investigated. High speed centrifugation of Brucellaserum mixtures was also used to increase the titer of Brucella agglutinins.

Several unsuccessful attempts also were made to adapt the Middlebrook-Dubos (2) hemagglutination method to the detection of antibodies against Brucella. In addition, paper chromatograms were made in attempts to differentiate specific from non-specific Brucella agglutinins by the method of Hess and Roepke (3).

Sera from 104 adults were studied. Of these subjects, 27 had brucellosis proved by culture, 28 had presumptive evidence of brucellosis, and 49 had no evidence of infection with Brucella and were classed as "normal" controls.

\section{METHODS}

Venous blood was obtained aseptically and allowed to clot in a sterile glass tube in a refrigerator. The serum was separated within a few hours. It was not heatinactivated but was tested immediately or stored in a deep-freeze cabinet at $0^{\circ}$ C. until tested.

Tube dilution agglutination method. The agglutinin titer was determined by a modification of the method of Fitch, Donham, Bishop, and Boyd (4). The serum was diluted two-fold serially from $1: 10$ to $1: 2,560$ with 0.85 per cent saline solution. Brucella abortus antigen (0.5 ml.) was added to $0.5 \mathrm{ml}$. of saline (control) and $0.5 \mathrm{ml}$. of each dilution of the serum in separate tubes." The

1 Sponsored by the Veterans Administration and published with the approval of the Chief Medical Director. The statements and conclusions published by the authors are the result of their own study and do not necessarily reflect the opinion or policy of the Veterans Administration.

2 Final dilution of the serum was carried thus to $1: 5,120$. antigen was prepared by diluting a heavy suspension of heat-killed $\mathrm{Br}$. abortus cells to $1: 100$ with saline solution. The stock antigen suspension (B.A.I.) was obtained from the Bureau of Animal Industry, U. S. Department of Agriculture, Beltsville, Maryland. After the addition of the antigen, the content of each tube was mixed by shaking and then incubated for 24 hours in a water bath at $37^{\circ} \mathrm{C}$. The tubes were then refrigerated at $5^{\circ} \mathrm{C}$. for 1 hour. They were examined immediately against a black background with mild agitation. The degree of agglutination was recorded as $0, \pm, 1+, 2+, 3+$, and $4+$ depending on the size and number of aggregates as well as the degree of clearing of the supernate. The agglutinin titer was taken to be the highest dilution of serum showing $1+$ or greater agglutination. The antibody titer as determined by all other methods was based on a comparable endpoint.

Rapid slide agglutination method. The method of Huddleson (5) was followed exactly. The serum was diluted serially from $1: 20$ through $1: 320$ by addition of

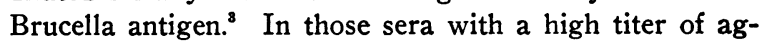
glutinin the serum was diluted $1: 16$ with 0.85 per cent saline solution prior to the addition of antigen to extend the range of dilution from $1: 320$ to $1: 5,120$. The mixtures were examined at room temperature after mixing and rotation on a glass plate for three minutes.

Castaneda slide or screening test (1). Br. abortus killed by heat and stained with methylene blue was obtained through the courtesy of M. Ruiz Castaneda, Hospital General, Mexico City. The test was performed by two methods which proved equally satisfactory. In the great majority of cases, capillary blood was obtained from the finger tip by a small puncture with a sharp, sterile needle using aseptic technique. A large drop of blood was touched immediately upon a glass plate. A small drop of the stained antigen was added to the blood from a tuberculin syringe fitted with a 26 gauge needle. The blood and antigen were quickly mixed with a sterile needle or platinum inoculating wire. Proper proportions of blood and antigen yielded a mixture having a bluegreen color. The glass plate was manually rocked in a circular fashion in the horizontal plane so as to swirl the mixed drop around gently in a depression on the surface of the glass plate. Any evidence of drying vitiated the results. Hence, the degree of agglutination was recorded within 60 seconds after mixing the blood and antigen. Complete $(4+)$ agglutination was indicated immediately

${ }^{8}$ Febrile $B r$. abortus antigen was obtained from Lederle Laboratories, Pearl River, N. Y. 
upon rotating the plate by the appearance of a dark blue peripheral ring of agglutinated antigen separated by centrifugal force from a distinct central red zone of erythrocytes. Lesser degrees of agglutination $(1+, 2+$, and $3+$ ) were indicated by slower and incomplete separation of the antigen from the erythrocytes. In a few cases where only frozen serum was available for study the serum was melted at room temperature and added to an equal volume of fresh, normal, whole human blood. The test was then carried out as described above.

"Blocking" antibodies. Only fresh, unheated sera were tested for "blocking" antibodies. The method was almost exactly the same as for the tube dilution agglutination test. After serial dilution of the suspected "blocking" serum and addition of the B.A.I. Br. abortus antigen, 0.03 $\mathrm{ml}$. of a potent human immune serum "was added to each tube and a saline control tube containing no "blocking" serum. Incubation and interpretation was carried out as in the tube dilution method. Blocking was indicated by less agglutination than found in the control tube.

- Tube dilution agglutination test revealed a titer of $1: 10,240$. The serum was stored in a deep-freeze cabinet.
Coombs antiglobulin agglutination test. As with the tube dilution method, serial dilutions of the patient's serum were prepared in saline. The final volume of the diluted serum in each tube was $1 \mathrm{ml}$. One ml. of B.A.I. $B r$. abortus antigen was added to each tube. After mixing, incubation was carried out at $37^{\circ} \mathrm{C}$. for 24 hours and at $5^{\circ} \mathrm{C}$. for 1 hour. The tubes were then centrifuged at 4,000 r.p.m. in a Sorvall angle centrifuge for 15 minutes. The supernate was aspirated and discarded. Two $\mathrm{ml}$. of 0.85 per cent saline solution was added to the sediment. After the sediment was resuspended by shaking, the tubes were again centrifuged. The washing of the sediment was carried out three times and the sediment was then resuspended in $0.5 \mathrm{ml}$. of saline. Coombs anti-humanglobulin rabbit serum ( $0.1 \mathrm{ml}$.) (6) was then added to each tube as well as a control tube with no immune serum. After mixing, incubation was carried out at $37^{\circ} \mathrm{C}$. for 30 minutes. Agglutination was then recorded.

Centrifugation agglutination test. The method was exactly as described for the Coombs method with omission

s Obtained from Ortho Pharmaceutical Corp., Raritan, N. J.

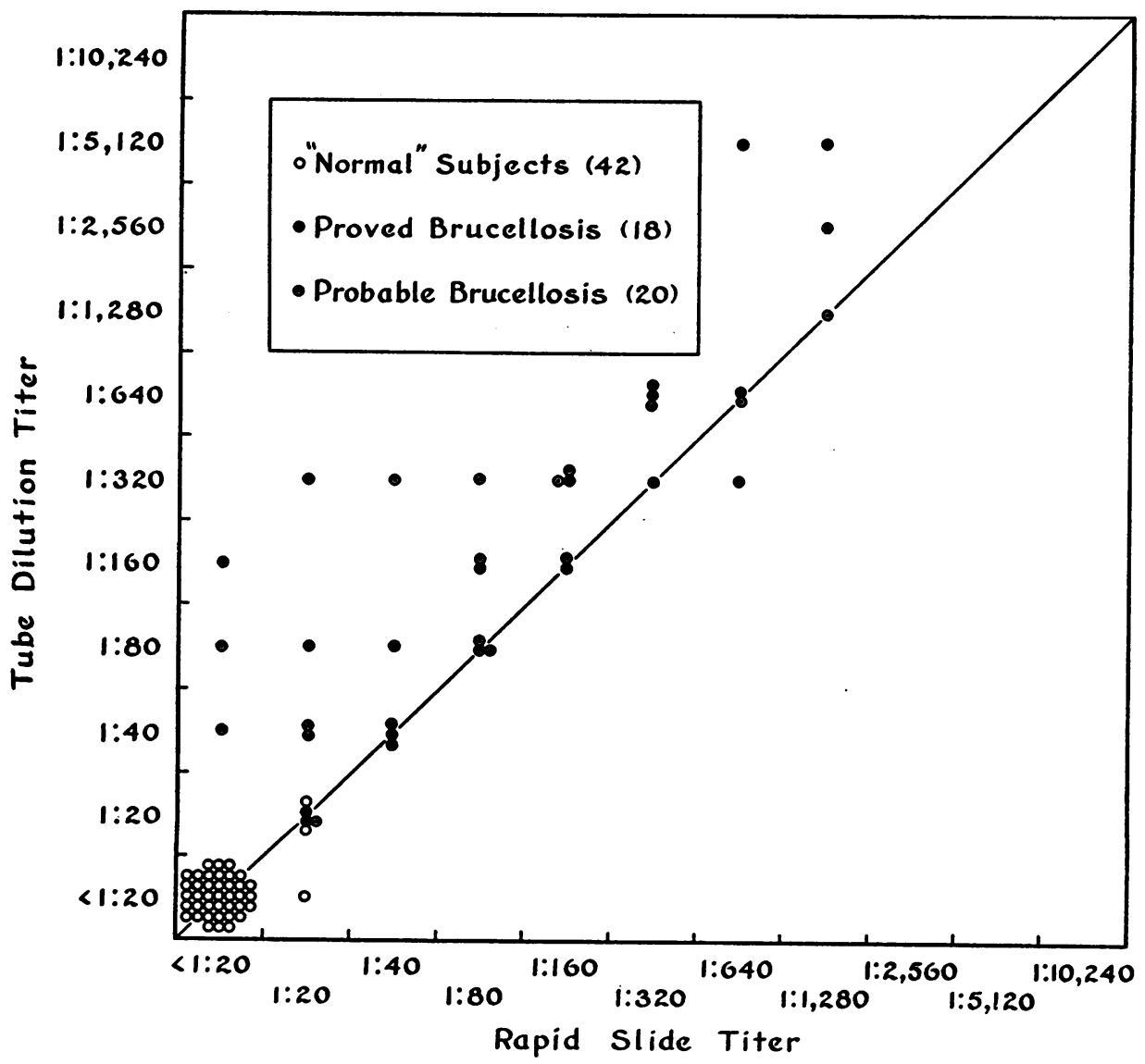

Fig. 1. Brucrlla Aggutinins in 80 Subjects by Tube Dilution and Huddleson Rapid SLIde Methods 
of the Coombs serum. The patient's serum was diluted serially with saline and an equal volume of B.A.I. Br. abortus antigen was then added. After mixing, the tubes were incubated at $37^{\circ} \mathrm{C}$. for 24 hours and at $5^{\circ} \mathrm{C}$. for 1 hour. They were then centrifuged in a Sorvall angle centrifuge at 4,000 r.p.m. for 15 minutes. Agglutination was recorded upon resuspension. Washing with saline proved unnecessary although it did make agglutination more definite.

Paper chromatograms. The method of Hess and Roepke (3) was used. A strip of S\&S 589 filter paper $(31 / 2 \times 3 / 4$ inches $)$ was placed on a flat surface and $0.02 \mathrm{ml}$. of serum allowed to soak in at one end. The strip was hung vertically with the spot of serum immersed in 0.05 M. potassium acid phthalate ( $\mathrm{pH}$ 6.2). After 15 minutes $B r$. abortus antigen ${ }^{6}$ was applied along the path of migration of the phthalate developer and serum with a fine brush. The strip was then washed with 1 per cent saline

\footnotetext{
6 The antigen was hematoxylin-stained $\mathrm{Br}$. abortus commonly used for the "ring" test for agglutinins in cream. The glycerine was removed by washing with saline. We are indebted to Dr. Martin H. Roepke, Division of Veterinary Medicine, University of Minnesota, St. Paul, for this antigen.
}

using a second brush on an absorbent towel. Migration of the antibody was taken to indicate the presence of specific Brucella agglutinin. Adsorption of the antibody to the paper and failure to migrate were typical of nonspecific antibody.

\section{RESULTS}

The serum of 80 subjects was tested for Brucella agglutinins by both the tube dilution and the rapid macroscopic (Huddleson) methods. The results are given in Figure 1. It was readily apparent that, with sera containing agglutinins for Brucella in a titer of $1: 40$ and above, the tube dilution method was more sensitive than the rapid slide method. It will be noted that five patients with brucellosis proved by culture and ten with probable brucellosis had an agglutinin titer of only $1: 80$ or less by either method. These patients, however, had contracted the disease at least 11 months earlier and had shown higher agglutinin titers during the first months of their illnesses. No "normal" subject was found to have

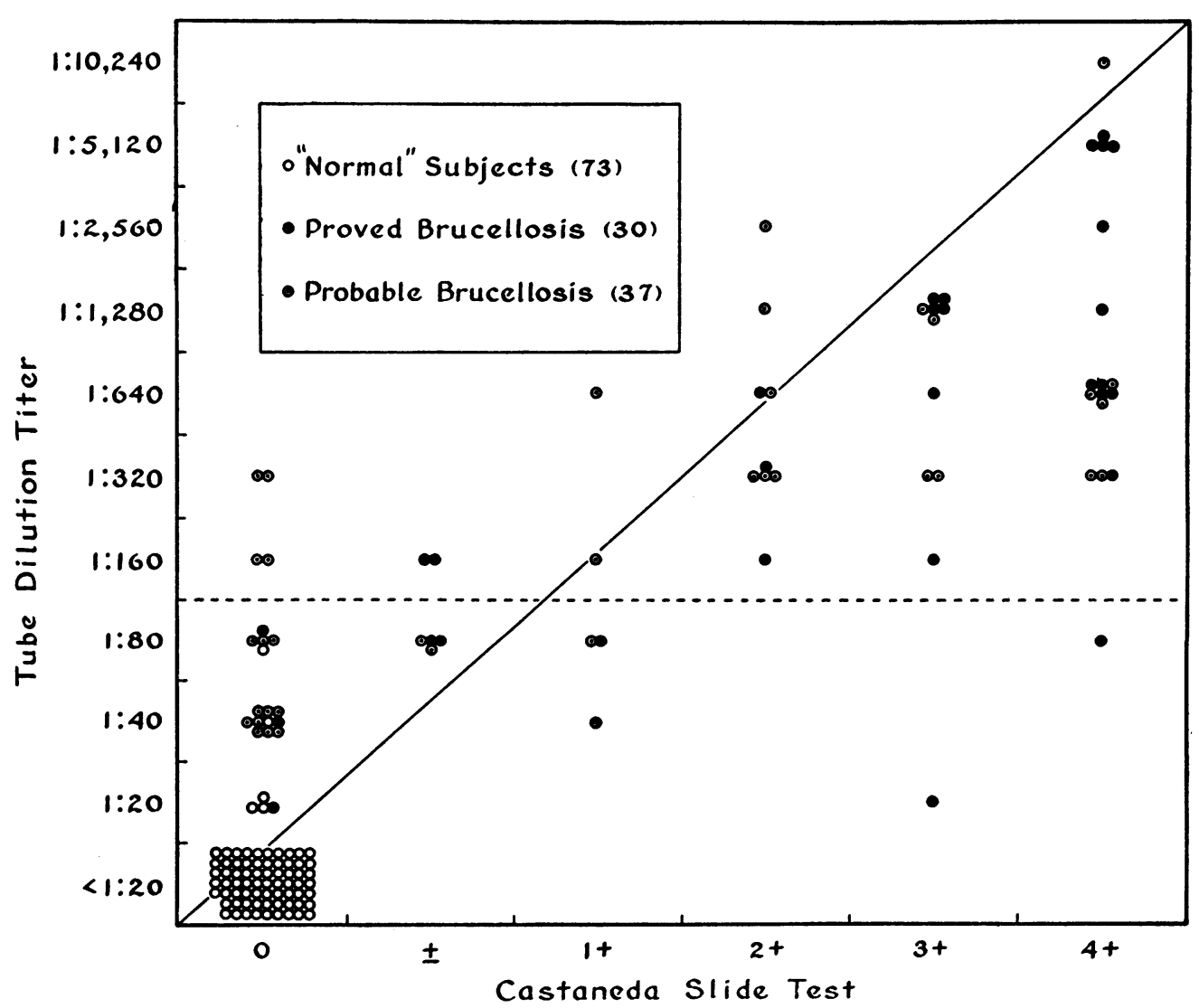

Fig. 2. The Castaneda Rapid Slide Test and Tube Dilution Brucella Aggutinin Titre IN 140 SUBJECts 


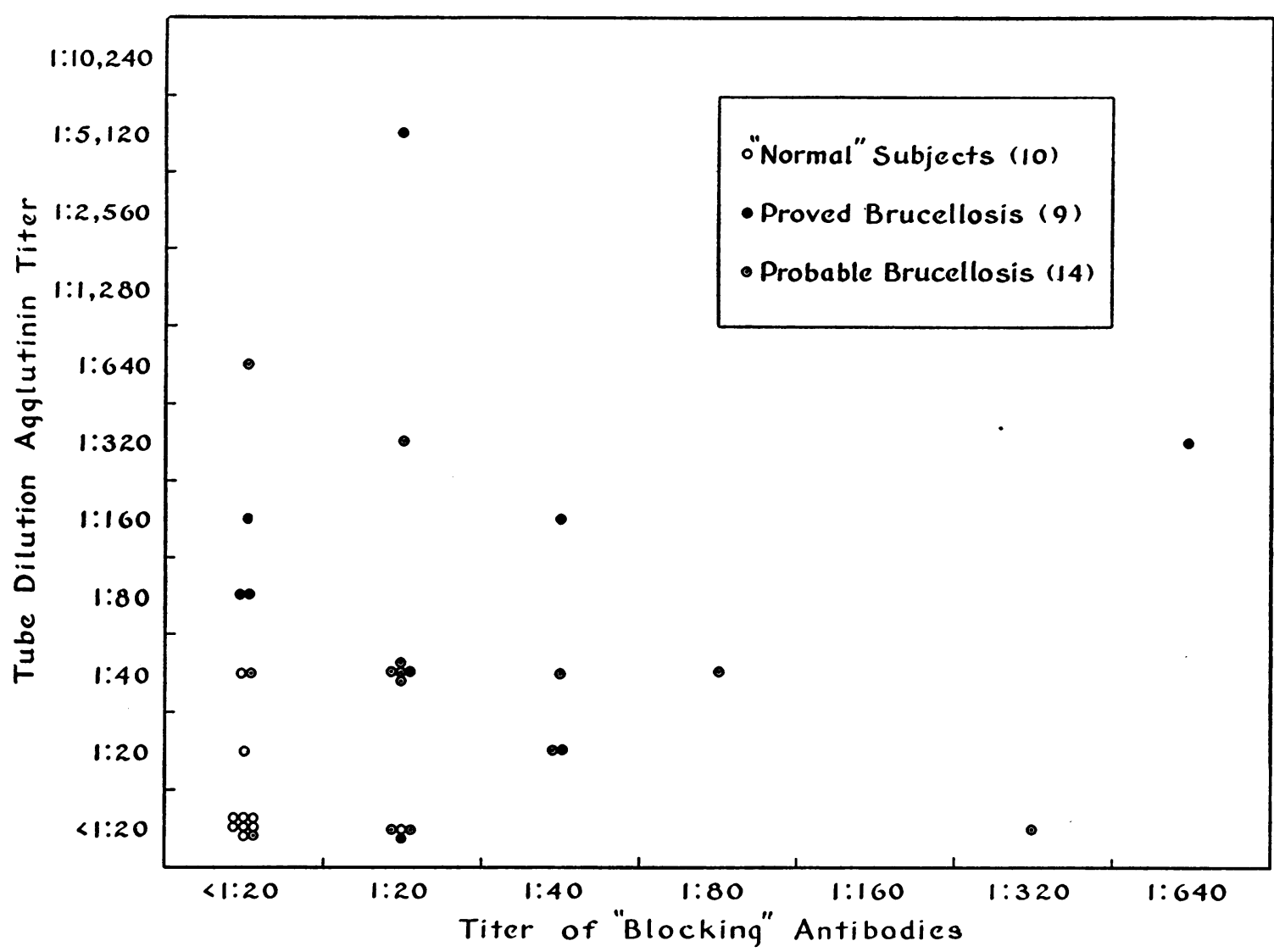

Fig. 3. The Titer of Brucella Agglutinins and "Blocking" Antibodies in 31 Subjects

an agglutinin titer greater than $1: 20$ by either the tube dilution or rapid slide methods. With few exceptions those subjects with an agglutinin titer of $1: 40$ or greater by either method acknowledged past or present symptoms commonly found in brucellosis and admitted exposure to Brucella through ingestion of unpasteurized milk or by contact with fresh meat. The diagnosis of brucellosis had been proved by the isolation of $B r$. abortus from the blood of 16 and $B r$. suis from the blood of 2 of the 38 patients with brucellosis, in Figure 1.

There were seven patients with proved and five with probable brucellosis whose serum showed the prozone inhibition phenomenon with the tube dilution agglutination method. The prozone exceeded a titer of $1: 20$ in only three individuals. In these patients the prozone extended through $1: 40$ in two and $1: 160$ in the other. The inhibition of agglutination was usually only partial in the prozone but it was complete at the 1:20 dilution in three patients. The tube dilution agglutinin titer in the entire group of 12 patients ranged from $1: 40$ to $1: 5,120$ (median $=1: 320$ ). A definite prozone was not seen in a single instance with the macroscopic rapid slide method.

The Castaneda rapid slide or screening test for Brucella agglutinins was compared with the tube dilution titer of the serum from 140 subjects, including 30 patients proved by culture to have brucellosis and 37 with probable brucellosis (Figure 2). There was a fair correlation between the agglutinin titer and the results of the Castaneda test. There were only two individuals, both recovered from brucellosis, whose blood gave a positive Castaneda test in the absence of an agglutinin titer of $1: 80$ or higher. None of the 73 "normal" subjects had a positive Castaneda test although Brucella agglutinins were detectable by the tube dilution method in a titer of $1: 80$ or less in 5 individuals. The sole "normal" subject whose serum had an agglutinin titer of $1: 80$ had received 


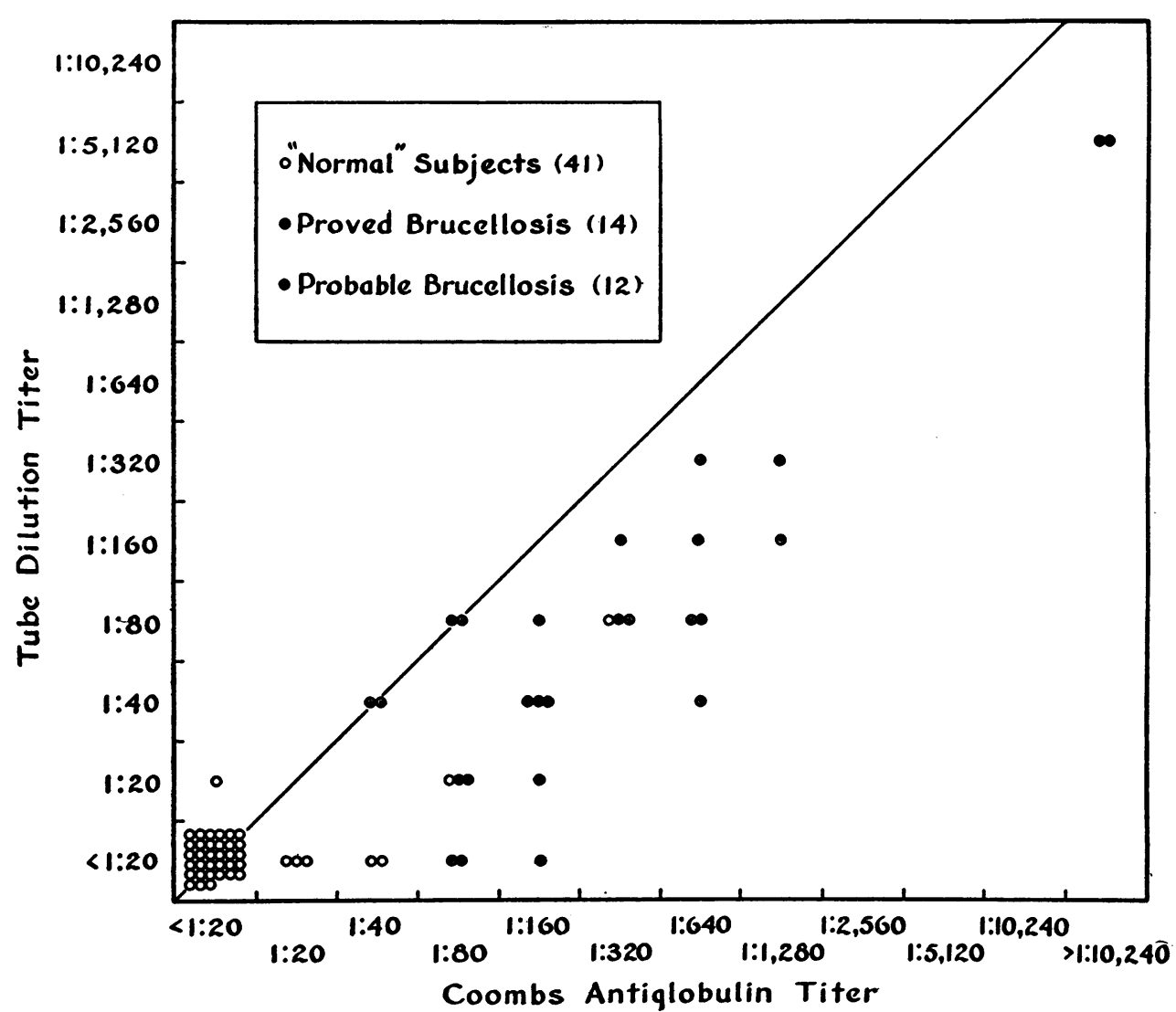

Fig. 4. The Brucella Agglutinin Titer in 67 Subjects by Tube Dilution and Coombs ANTtGlobulin Methods

a booster dose of $0.5 \mathrm{ml}$. cholera vaccine 6 weeks earlier. Four patients with probable brucellosis and two with bacteremic, active brucellosis did not have a definitely positive Castaneda test although their serum agglutinin titer was $1: 160$ to $1: 320$. The Castaneda test was positive with 86 per cent of 44 patients whose serum had an agglutinin titer of $1: 160$ or greater and was positive with only 5 per cent of subjects whose serum had a titer of $1: 80$ or less. Of the seven patients with proved brucellosis, whose Castaneda test was not positive, only two had active brucellosis at the time the test was done; the others had recovered from the disease. No false positive Castaneda tests were observed when correctly done with normal blood. If the blood-antigen mixtures were allowed to stand and dry, however, false "agglutination" frequently resulted.

Fresh, unheated serum was obtained from 31 individuals to be tested for "blocking" antibodies against Brucella agglutinins. Only 1 of 10 nor- mal subjects showed any "blocking" and then only a slight suppression of agglutination in a dilution of 1:20 (Figure 3). Twenty-three selected patients with brucellosis were included; the diagnosis was proved by isolation of $\mathrm{Br}$. abortus from the blood of nine. The patients were selected because their tube dilution agglutination test showed an inhibition prozone or only a low titer of agglutinins. Many of these patients had been ill for more than a year and most of them had been exposed to Brucella for many years.

There was little correlation between the titer of Brucella agglutinins and the titer of "blocking" antibodies. The titer of "blocking" antibodies exceeded 1:40 in only three patients. The "blocking" or inhibition of agglutination was not complete except occasionally in the lowest dilutions.

The Coombs antiglobulin method proved effective in increasing the sensitivity of the agglutination method without destroying its specificity (Figure 4). The Coombs method frequently in- 
creased by fourfold or more the agglutinin titer of the serum from patients with brucellosis. Only two subjects without brucellosis had a titer over $1: 40$ by the Coombs method; one man had recently recovered from a dysentery caused by Salmonella oranienburg and the other had been given cholera vaccine. Several of the patients with brucellosis had recovered from the disease and their agglutinin titer was less than 1:160 by the tube dilution method; their Coombs antiglobulin titer, however, ranged as high as $1: 640$. The Coombs antiglobulin method nearly always removed the inhibition prozones.

Serial washings and addition of antiglobulin rabbit serum, which are an integral part of the Coombs procedure, did not contribute as much to the increase in agglutinin titer as did the centrifugation incident to the washing procedure. The most time-consuming and expensive features of the Coombs test were therefore eliminated. The serum dilutions need only be mixed with the Brucella antigen, incubated and centrifuged in order to obtain the highest agglutinin titer of the serum. Figure 5 compares the agglutinin titer of the serum of 102 subjects by the tube dilution and centrifugation methods. The results were practically the same as with the more cumbersome Coombs antiglobulin method. Only three of 47 "normal" subjects showed a Brucella agglutinin titer of more than 1:80 after centrifugation; one of these men was infected with $S$. oranienburg and two had received cholera vaccine. Generally the agglutinin titer of sera from patients with brucellosis was increased by four to eightfold by the centrifugation method. Centrifugation almost completely eliminated inhibition prozones and the "blocking" phenomenon. All the patients with proved brucellosis and most of those with proba-

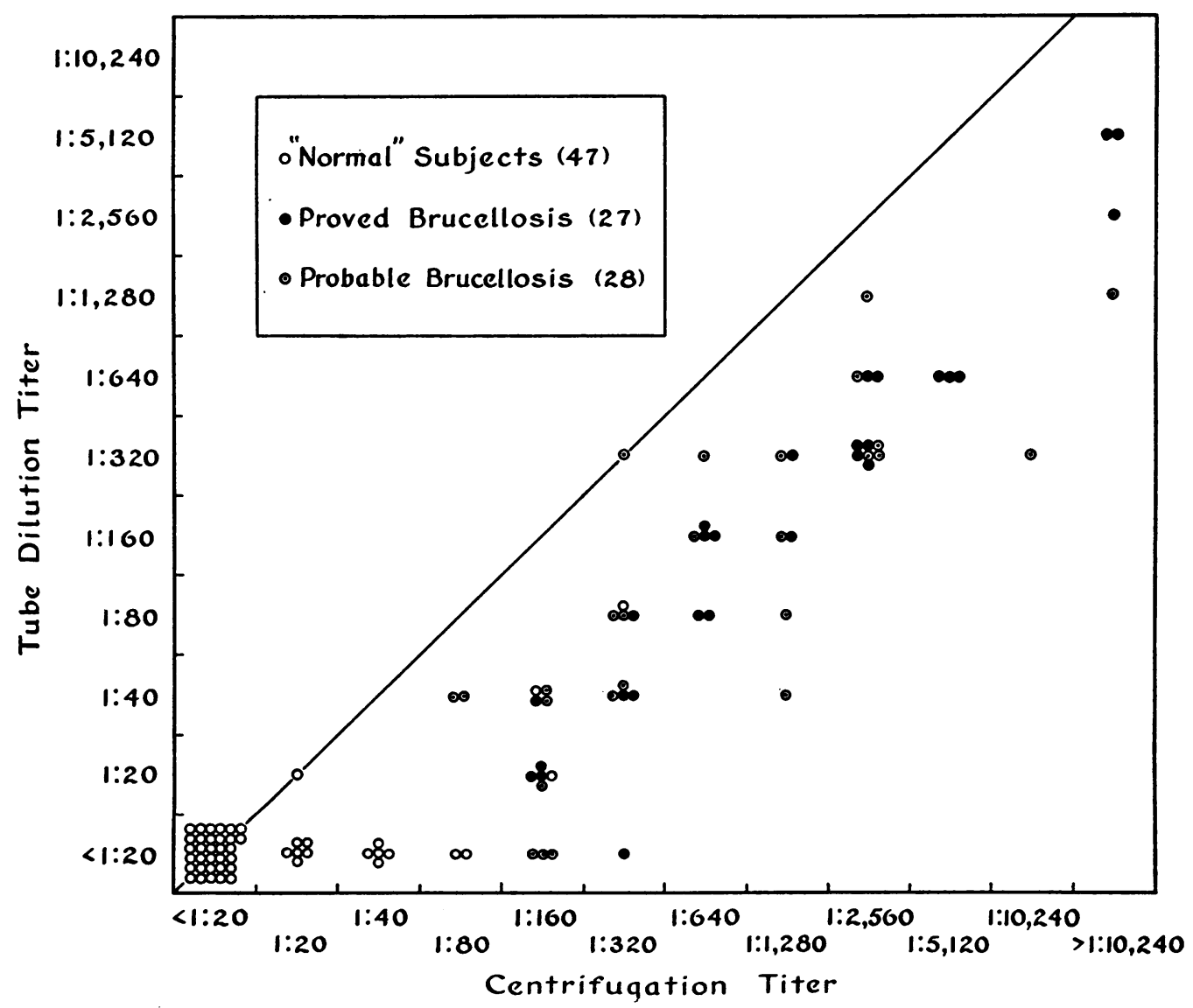

Fig. 5. The Brucella Agglutinin Titer in 102 Subjects by the Tube Dilution and Centrifugation Methods 


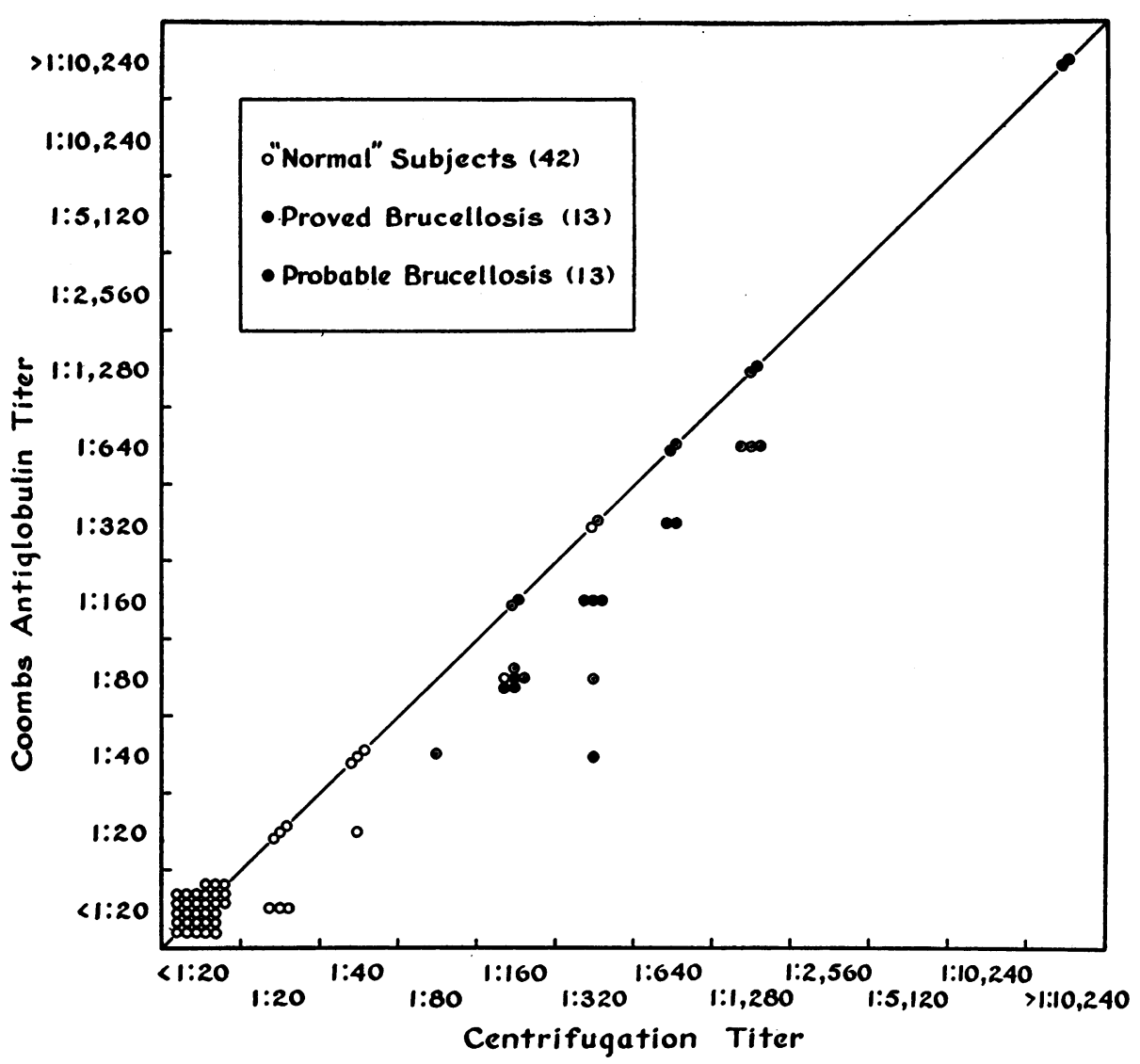

Fig. 6. Brucella Agglutinins by Coombs Antiglobulin and Centrifugation Methods in 68 Subjects

ble brucellosis whose tube dilution agglutinin titer was less than 1:160 had contracted brucellosis many months earlier and were asymptomatic when tested.

Some variations of the centrifugation method were tried. Although washing of the antigenantibody was not necessary, it removed background turbidity and made the agglutinated precipitate more compact. Interpretation of the degree of agglutination was thus made easier. The data given in Figures 5 and 6 were obtained by centrifugation of the incubated serum-antigen mixtures in a Sorvall angle centrifuge at 4,000 r.p.m. for 15 minutes. Almost identical results were obtained in comparative studies with six immune human sera using an International centrifuge (No. 2) at 2,500 r.p.m. for 30 minutes.

Close correlation between the results with the Coombs antiglobulin and the centrifugation methods was demonstrated by simultaneous examina- tion of serum from 68 subjects (Figure 6). In some cases the centrifugation method gave an agglutinin titer two to four dilutions higher than did the Coombs method; in only one instance was the reverse true. Two "normal" individuals, previously mentioned, had agglutinin titers over $1: 40$ by both methods; one had a recent Salmonella dysentery and the other received cholera vaccine. The patients with brucellosis did not all have active disease when tested; several with low titers had recovered or were convalescing.

The results of paper chromatograms for Brucella antibody in the serum of 23 subjects are given in Table $I$. The normal individuals had negative chromatograms. All but one patient with brucellosis had "specific" Brucella antibody in his serum; the one exception occurred with a patient tested more than four years after he contracted the disease and long after he had recovered. The chromatogram showed "specific" antibody to be 
TABLE I

Comparison of the Brucella agglutinin titer (tube dilution) and the paper chromatogram of the serum from 23 subjects

\begin{tabular}{|c|c|c|c|c|c|}
\hline \multirow{2}{*}{$\begin{array}{l}\text { Status and } \\
\text { no. of } \\
\text { patients }\end{array}$} & \multirow{2}{*}{$\begin{array}{l}\text { Tube dilution } \\
\text { Brucella } \\
\text { agglutinin } \\
\text { titer }\end{array}$} & \multirow{2}{*}{$\underset{\text { Nega- }}{\text { tive }}$} & \multicolumn{3}{|c|}{$\begin{array}{c}\text { Paper chromatogram* } \\
\text { Positive }\end{array}$} \\
\hline & & & $\begin{array}{l}\text { Non- } \\
\text { specific }\end{array}$ & Mixed & Specific \\
\hline Normal-4 & $<1: 20$ & 4 & 0 & 0 & 0 \\
\hline $\begin{array}{l}\text { Probable } \\
\text { brucellosis } \\
\quad-6\end{array}$ & $\begin{array}{c}<1: 20 \\
1: 80 \\
1: 160 \\
1: 640\end{array}$ & 0 & 0 & 0 & $\begin{array}{r}6 \\
\text { (1) } \\
(1) \\
(1) \\
(3)\end{array}$ \\
\hline $\begin{array}{l}\text { Proved } \\
\text { brucellosis } \\
-13\end{array}$ & $\begin{array}{l}1: 20 \\
1: 40 \\
1: 80 \\
1: 320 \\
1: 640 \\
1: 1,280\end{array}$ & 1 (1) & 0 & $\begin{array}{l}1 \\
\text { (1) }\end{array}$ & $\begin{aligned} & 11 \\
& (1) \\
& (2) \\
& (3) \\
& (4) \\
& (1)\end{aligned}$ \\
\hline & Totals $=$ & 5 & 0 & 1 & 17 \\
\hline
\end{tabular}

* Method of Hess and Roepke (3).

present as early as 3 days and as late as 39 months after the onset of symptoms. The intensity of the fixation of antigen by "specific" antibody on the paper strip correlated only roughly with the Brucella agglutinin titer by the tube dilution method. A "non-specific" antibody $(1+)$ was found in the serum of one patient with proved brucellosis due to $\mathrm{Br}$. abortus during convalescence; his serum also contained "specific" antibody $(4+)$ but the agglutinin titer was only $1: 80$.
Six normal adults were given cholera vaccine (Table II). The dose was $0.5 \mathrm{ml}$. subcutaneously followed by $1.0 \mathrm{ml}$. seven days later. Serum was obtained before each injection and weekly thereafter for six weeks. Brucella agglutinins were measured by the tube dilution and paper chromatographic methods. Four of the six showed a maximum Brucella agglutinin titer of $1: 20$ to $1: 320$ two weeks after the first dose of cholera vaccine. The titer did not exceed 1:80 in any subject at six weeks. Paper chromatograms showed that the Brucella agglutinins were composed of a mixture of "specific" and "non-specific" antibodies.

\section{DISCUSSION}

In our hands the tube dilution method has. proved to be the most reliable test for Brucella agglutinins. It was the method used by Wright (7) when he first described the agglutination test for differentiating Malta fever from typhoid fever in 1897. It measures both the quantity and avidity of the serum antibody with a sensitivity and specificity offered by no other method. It would be an advance if the tube dilution method were to be generally accepted and used as the preferred method for Brucella agglutinin titration in laboratories throughout the world (8). Unfortunately a standard antigen is not universally available for the test. The B.A.I. antigen widely used by veterinarians in this country is an excellent antigen but it is not available for use with human sera except in a very few laboratories. Details of the method, including preparation of the antigen, were

TABLE II

Brucella agglutinin titer (tube dilution) and paper chromatogram of six normal subjects given cholera vaccine

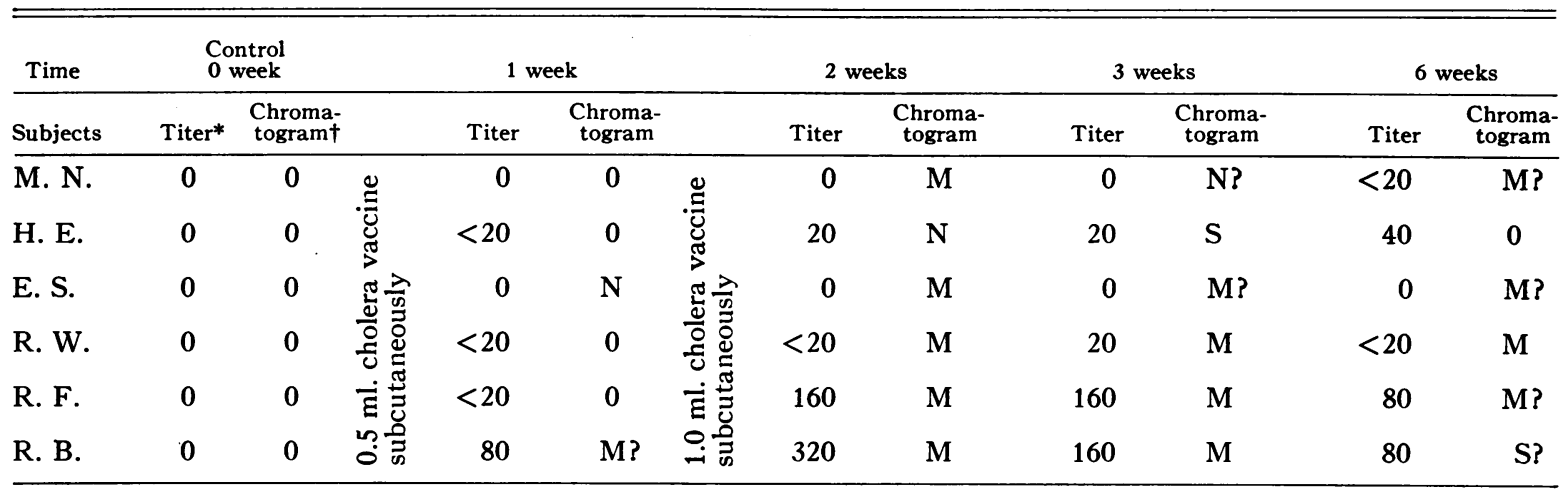

* Reciprocal of final dilution giving $1+$ or greater agglutination of $\mathrm{Br}$. abortus antigen.

$\dagger$ Method of Hess and Roepke (3). $\mathrm{S}=$ "specific." $\mathrm{N}=$ "non-specific." $\mathrm{M}=$ mixed. $0=$ negative. 
worked out in detail by Fitch (4). Variations in antigens and method make it desirable to have standard immune sera available for comparisons among laboratories. The few comparative studies that have been published indicate that there is an appalling variation in results in different laboratories when the same sera are tested for Brucella agglutinins by various non-standard methods $(9,10)$.

The data presented in Figure 1 amply demonstrate that the tube dilution method is more sensitive and just as specific as the rapid macroscopic slide method of Huddleson dešpite previous conclusions to the contrary (11). The rapid slide method is less precise and less reproducible, often leading to considerable variation in results in different laboratories $(9,10)$. Furthermore, certain lots of rapid slide antigen may be contaminated with agar and give rise to false positive reactions (12). Inhibition prozones were not observed with the rapid slide method yet were rarely troublesome with the tube dilution method. In fact the prozone obscured results of tube dilution agglutination tests in only one of several thousand such sera examined in this laboratory.

For purposes of rapid serologic diagnosis we have preferred the Castaneda rapid slide or screening test (1). As shown in Figure 2, this test has proved to be a suitably accurate measure of the presence and quantity of Brucella agglutinins in human sera. The test requires few materials and can be done in a few minutes at the patient's bedside. We have observed no nonspecific reactions and the test is seldom negative in patients with active brucellosis.

It has been stated by several authors that patients with active brucellosis frequently have no Brucella agglutinins in their serum $(1,13-19)$. This situation has been said to be particularly common in chronic brucellosis (20-23). One might explain its occurrence by localization or sequestration of the Brucella in an avascular focus (23). The studies of Griffitts (24) led some to believe that "blocking" or "incomplete" antibodies often might be found in brucellosis. Such antibodies have been found in certain sera by Schuhardt (25), Renoux (26-28) and Jones and Wilson (29). Our own studies, however, indicate that such antibodies are seldom found in a titer which would significantly alter the agglutinin titer.
We have observed only one of more than 200 patients with brucellosis whose tube dilution agglutinin titer was less than 1:20 at any time during the active phase of his disease exclusive of the first two weeks. The one exception occurred in a veterinarian with recurrent, severe brucellosis caused by $\mathrm{Br}$. abortus. ${ }^{7}$ On several occasions his tube dilution agglutination test was reported to be "negative" by another reliable laboratory although he had a bacteremia. Earlier and subsequent agglutinins were demonstrated in a titer of $1: 160$ to $1: 640$ on several occasions. There usually was an inhibition prozone extending through a dilution of $1: 160$. "Blocking" antibodies were demonstrated in his serum at a dilution as high as $1: 640$. This undoubtedly accounted for the difficulties with agglutination tests in this case. The blocking activity of his serum was reduced, but not entirely inhibited either by heating to $56^{\circ} \mathrm{C}$. for 30 minutes or by the addition of 5 per cent bovine albumin (Cohn's fraction V) or 5 per cent sodium chloride solution. The blocking activity of his and other sera was completely overcome by high-speed centrifugation of the serum-antigen mixtures. The blocking activity of his serum was also apparent with the macroscopic slide method (Huddleson).

The mechanism of the blocking phenomenon is unknown. The most reasonable explanation would seem to be the presence of Brucella antibody which is incomplete, lacking a chemical group necessary for spontaneous adherence of one sensitized particle of antigen to others, and yet possessing undiminished avidity for union with the antigen particle itself. The serum containing incomplete antibody, however, is able to cause agglutination of sensitized antigen particles after high-speed centrifugation. Hence, the defect in chemical grouping may be only a matter of slight change in configuration and not a complete lack of the necessary group(s).

That "blocking" antibodies are capable of uniting with their homologous antigen has been amply proved by the indirect Coombs method. The latter method has been recommended by Jones and Wilson (29) and by Wilson and Merrifield (30) for increasing the sensitivity of Brucella agglutination tests, eliminating prozones and overcoming

\footnotetext{
7 We are indebted to Dr. Wesley W. Spink, University of Minnesota Hospitals, for this serum.
} 
blocking antibodies. We have confirmed their findings with regard to the Coombs method (Figure 4). The Coombs method, however, is slow and requires very meticulous washing of serumantigen mixtures to avoid false negative results. Also, the Coombs antiglobulin rabbit serum is too expensive for routine titration of Brucella agglutinins. Simple centrifugation accomplishes the same result as the Coombs method with greater simplicity and speed (Figures 5 and 6). Prozones and the blocking phenomenon were rarely seen after centrifugation. Indeed, centrifugation has been used by Feinberg and Wright (31) to allow brief incubation for one-half hour at $37^{\circ} \mathrm{C}$. They concluded that with the tube dilution method it was better to incubate at $56^{\circ} \mathrm{C}$. for 16 hours in order to lessen cross-reactions with non-specific agglutinins such as seen after tularemia and cholera vaccine. It has been our experience that heating sera obtained after cholera vaccination at $56^{\circ}$ C. for 30 minutes does not significantly decrease their Brucella agglutinin titer (32). In our hands centrifugation did not permit brief incubation at $37^{\circ} \mathrm{C}$.; agglutinin titers after 3 to 6 hours were generally lower than after 24 hours at $37^{\circ} \mathrm{C}$. The possibility of brief incubation at $56^{\circ} \mathrm{C}$. followed by centrifugation is now under investigation.

Brief experience with the paper chromatographic method of Hess and Roepke (3) indicates that although it is a sensitive method for detecting Brucella agglutinins in human sera the chromatograms are often difficult to interpret. Patients with brucellosis seldom show "non-specific" antibodies. However, normal subjects vaccinated with cholera vaccine tend to show a mixture of "specific" and "non-specific" agglutinins. The method does not seem to differentiate clearly Brucella agglutinins arising from cholera vaccination from those caused by Brucella infection. This is not surprising since Brucella possess an antigen closely related to the "H" antigen of Vibrio comma (33).

\section{SUMMARY AND CONCLUSIONS}

1. Comparative studies with over 100 human sera were made to evaluate methods for demonstrating Brucella agglutinins. The methods included the tube dilution, rapid macroscopic slide (Huddleson), rapid slide (Castaneda), indirect Coombs antiglobulin, "blocking," centrifugation and paper chromatographic methods.
2. The tube dilution method is more sensitive than Huddleson's rapid macroscopic slide test.

3. Castaneda's rapid slide test is useful as a quick bedside method to detect active human brucellosis. However, it gives only a crude index of the quantity of agglutinin.

4. The "blocking test" is seldom useful. Only one of more than 200 patients with brucellosis had sufficient "blocking" antibody to obscure the results of the tube dilution agglutination test.

5. The indirect Coombs antiglobulin method is a sensitive but tedious and expensive procedure for titrating Brucella agglutinins. It eliminates the problem of prozones and "blocking."

6. High-speed centrifugation after incubation of serum-antigen mixtures yields a sensitivity equal to or greater than that of the Coombs method with greater speed and simplicity.

7. Paper chromatography is a sensitive technique for detecting Brucella agglutinins in human sera but its usefulness in differentiating "specific" from "non-specific" agglutinins remains in doubt.

8. The tube dilution method, with a standard Brucella antigen and standard immune sera as controls, has been found to be the most useful, practical procedure for the demonstration of Brucella agglutinins.

\section{REFERENCES}

1a. Castaneda, M. Ruiz, Brucellosis. Monograph series

b. Spink, W. W., and Anderson, D., Correlation of a rapid slide-agglutination test (Castaneda) with a tube-agglutination test in screening suspected cases of human brucellosis. J. Lab. \& Clin. Med., 1952, 40, 593.

2. Middlebrook, G., and Dubos, R. J., Specific serum agglutination of erythrocytes sensitized with extracts of tubercle bacilli. J. Exper. Med., 1948, 88, 521.

3. Hess, W. R., and Roepke, M. H., A non-specific Brucella agglutinating substance in bovine serum. Proc. Soc. Exper. Biol. \& Med., 1951, 77, 469.

4. Fitch, C. P., Donham, C. R., Bishop, L. M., and Boyd, W. L., Studies of the test tube agglutination test for the diagnosis of Bang's disease (contagious abortion). Tech. Bull., University of Minnesota Agric. Exper. Sta., 1930, 73, 1.

5. Gould, S. E., and Huddleson, I. F., Diagnostic methods in undulant fever (brucellosis); with results of a survey of 8,124 persons. J. A. M. A., 1937, 109, 1971.

6. Coombs, R. R. A., Mourant, A. E., and Race, R. R., A new test for the detection of weak and "incomplete” Rh agglutinins. Brit. J. Exper. Path., 1945, 26, 255. 
7. Wright, A. E., and Smith, F., On the application of the serum test to the differential diagnosis of typhoid and Malta fever. Lancet, 1897, 1, 656.

8. Spink, W. W., McCullough, N. B., Hutchings, L. M., and Mingle, C. K., Diagnostic criteria for human brucellosis. Report No. 2 of the National Research Council, Committee on Public Health Aspects of Brucellosis. J. A. M. A., 1952, 149, 805.

9. Eisele, C. W., McCullough, N. B., and Beal, G. A., Discrepancies in the agglutination test for brucellosis as performed with various antigens and as reported from different laboratories. J. Lab. \& Clin. Med., 1947, 32, 847.

10. Griggs, J. F., and Case, L. W., Variations in Brucella agglutination reactions in different laboratories. Am. J. Clin. Path., 1948, 18, 506.

11. Welch, H., and Mickle, F. L., Comparison of the Huddleson slide test with a macroscopic tube test in undulant fever. J. Lab. \& Clin. Med., 1931, 17, 67.

12. Shipe, E. L., Jr., and Holtman, D. F., Production of less sensitive rapid antigen for diagnosis of $\mathrm{Bru}$ cella infections. Proc. Soc. Exper. Biol. \& Med., 1948, 68, 546.

13. Carpenter, C. M., Boak, R., and Chapman, O. D., The significance of Brucella abortus agglutinins in human serum. J. Immunol., 1929, 17, 65.

14. Wainwright, C. W., Malta fever in the United States. Bull. Johns Hopkins Hosp., 1929, 45, 133.

15. Gilbert, R., and Dacey, H. G., The isolation of an organism of the abortus-melitensis group from a blood clot, the serum of which failed to give agglutination with B. abortus. J. Lab. \& Clin. Med., 1932, 17, 345 .

16. Johns, E. P., Campbell, F. J. H., and Tennant, C. S., A serological and clinical investigation of individuals exposed to $\mathrm{Br}$. abortus. Canad. M. A. J., 1932, 27, 490 .

17. Keller, A. E., Pharris, C., and Gaub, W. H., Diagnosis of undulant fever. The opsonocytophagic, allergic and agglutination reactions. J. A. M. A., 1936, 107, 1369.

18. Meyer, K. F., and Eddie, B., Laboratory infections due to Brucella. J. Infect. Dis., 1941, 68, 24.

19. Castaneda, M. R., Tovar, R., and Velez, R., Studies on brucellosis in Mexico. Comparative study of various diagnostic tests and classification of the isolated bacteria. J. Infect. Dis., 1942, 70, 97.

20. Smith, D. T., and Poston, M. A., Some unusual cases of Brucella infection. Trans. Am. Clin. \& Climat. Assoc., 1937, 52, 9.

21. Evans, A. C., Robinson, F. H., and Baumgartner, L., Studies on chronic brucellosis. IV. An evaluation of the diagnostic laboratory tests. Pub. Health Rep., 1938, 53, 1507.

22. Evans, A. C., Difficulties in the diagnosis of chronic brucellosis. Am. J. Trop. Med., 1939, 19, 319.

23. Weed, L. A., Importance of bacteriology in orthopedic surgery. Proc. Staff Meet., Mayo Clinic, 1952, 27, 225.

24. Griffitts, J. J., Agglutination and an agglutinin-"blocking" property in serums from known cases of brucellosis. Pub. Health Rep., 1947, 62, 865.

25. Schuhardt, V. T., Woodfin, H. W., and Knolle, K. C., A heat-labile Brucella-agglutinin-blocking factor in human sera. J. Bact., 1951, 61, 299.

26. Renoux, Gérard, Anticorps bloquants dans le sérum de sujets brucelliques. I. Leur mise en évidence. Ann. Inst. Pasteur, 1950, 78, 798.

27. Renoux, Gérard, Anticorps bloquants dans le sérum de sujets brucelliques. II. Leur role dans le phénoméne d'agglutination paradoxale. Ann. Inst. Pasteur, 1950, 79, 232.

28. Carrere, L., and Renoux, G., Anticorps bloquants dans le sérum de sujets brucelliques. III. Leur place par rapport a l'apparition des anticorps agglutinants. Ann. Inst. Pasteur, 1951, 80, 103.

29. Jones, L. O., and Wilson, M. M., Serum agglutinins in brucellosis. Nature, 1951, 167, 558.

30. Wilson, M. M., and Merrifield, E. V. O., The antiglobulin (.Coombs) test in brucellosis. Lancet, 1951, 2, 913.

31. Feinberg, R. J., and Wright, G. G., Factors influencing the agglutination titration in human brucellosis. J. Immunol., 1951, 67, 115.

32. Hall, W. H., Studies of immunity to brucellosis and the bactericidal action of human blood against Brucella. Ph.D. Thesis, Univ. of Minnesota Graduate School, 1950.

33. McCullough, N. B., Eisele, C. W., and Beal, G. A., Antigenic relationship of Brucella and Vibrio comma. J. Infect. Dis., 1948, 83, 55. 